\title{
Caught between Traditional Ways of Life and Economic Development: Interactions between Indigenous Peoples and an Oil Company in Numto Nature Park
}

\author{
Dr. Maria Tysiachniouk $\star$ \\ Centre for Independent Social Research, Russia, Durham University, Faculty of Geography, \\ UK; University of Rovaniemi, Faculty of Law, Finland, Wageningen University, Environ- \\ mental Policy Group, the Netherlands
}

\author{
Dr. Irina Olimpieva \\ Centre for Independent Social Research, Russia
}

\begin{abstract}
The paper examines the conflict between indigenous people living in Numto Nature Park in the Khanty-Mansy region of Russia and the oil company Surgutneftegaz, which is trying to expand to new areas of the Park for industrial development. We analyse this conflict by looking at different perceptions concerning the threats and benefits underpinning the conflicting parties' arguments. We show that the oil company, whose approach is based on the principles of benefit sharing, seeks to provide economic benefits as well as infrastructure to ensure development in the indigenous community. In contrast, the indigenous people in Numto prioritise environmental safety and the possibility of maintaining their traditional ways of life, which means eliminating the negative impacts of oil development on fisheries, reindeer herding and the general state of the environment.

The study indicates that focusing on indigenous peoples' and oil companies' differences concerning perceptions of threats and benefits provides a better understanding of desirable benefit-sharing arrangements between oil companies and indigenous peoples in areas that have so far only been marginally affected by industrialisation and modernisation. This insight suggests that the introduction of community-centred perspectives emphasising cultural and environmental security in benefit-sharing policies in oil companies could improve practices. ${ }^{1}$
\end{abstract}

\footnotetext{
^Correspondence to: Dr. Maria Tysiachniouk, email: tysiachn@yandex.ru, 197022 Kamenoostrovski 69, apt.15, St. Petersburg, Russia

(C) 2019 Dr. Maria Tysiachniouk \& Dr. Irina Olimpieva. This is an Open Access article distributed under the terms of the Creative Commons Attribution-NonCommercial 4.0 International License (https://creativecommons.org/licenses/by$\mathrm{nc} / 4.0 /$ ), allowing third parties to share their work (copy, distribute, transmit) and to adapt it, under the condition that the authors are given credit, that the work is not used for commercial purposes, and that in the event of reuse or distribution, the terms of this license are made clear.

Citation: Dr. Maria Tysiachniouk \& Dr. Irina Olimpieva. "Caught between Traditional Ways of Life and Economic Devel-

opment: Interactions between Indigenous Peoples and an Oil Company in Numto Nature Park" Arctic Review on Law and Politics, Vol. 10, 2019, pp. 56-78. http://dx.doi.org/10.23865/arctic.vxx.1207
} 
The analysis draws on interviews with members of the indigenous Nenets and Khanty peoples of Numto Park as well as representatives of Surgutneftegaz, NGOs, the regional administration and the Numto Park administration.

Keywords: indigenous people; benefit sharing; traditional lifestyle; economic development; oil extraction; conflict

Responsible Editor: Noor Johnson, National Snow and Ice Data Center, University of Colorado Boulder, USA

Received: March 2018; Accepted: February 2019; Published: March 2019

\section{Introduction}

Indigenous peoples inhabit most of the areas containing oil and gas deposits in the Russian Arctic and sub-Arctic regions. Rapid industrial development triggered by oil extraction has an impact on the environment and on those indigenous peoples living off their natural habitats, putting their cultural and environmental security at risk. Cultural security represents the ability of a social group to maintain its character and traditions under changing conditions and different kinds of threats; the group faces the challenge of preserving its traditional identity in the face of economic expansion and modernisation. ${ }^{2}$

These threats to indigenous culture seem unavoidable when extractive industries operate on indigenous lands. However, benefit-sharing arrangements in some Russian oil extraction regions attest to the possibility of peaceful coexistence between oil companies and indigenous peoples. Examples include the Nenets Autonomous Okrug (NAO), where indigenous people have received adequate funds for building reindeer meat processing plants ${ }^{3,4}$ and Sakhalin Island, where indigenous languages and traditions have been revitalised through companies' funding. ${ }^{5}$

The creation of protected areas or reserves is a strategy employed around the world to protect ecological integrity in the context of regional development. Protected areas are established in very different ways depending on the context; while they have the potential to protect indigenous peoples' traditional land uses and ways of life, in some cases, indigenous peoples have been evicted from these areas and prohibited from pursuing their traditional activities. ${ }^{6}$ In Russia, the establishment of nature parks has the potential to preserve both valuable ecosystems and indigenous peoples' traditional ways of life in the area. ${ }^{7}$ Given the country's resource-dependent economy, the oil and gas industry has sought to develop oil infrastructure in protected areas, leading to conflicts over the role of these areas in supporting either economic development or traditional indigenous use.

This paper analyses one such case, Numto Nature Park in the Khanty-Mansy Autonomous Okrug (KhMAO), which has become an arena of conflict between indigenous people, mostly Forest Nenets who live in the park, and the oil company Surgutneftegaz. Our analysis takes into account the different perceptions of 


\section{Dr. Maria Tysiachniouk and Dr. Irina Olimpieva}

economic, ecological and cultural threats underpinning the conflicting parties' arguments. We trace the history of how Surgutneftegaz and the Forest Nenets communities inside the park have come to view each other, and highlight the divergence in the parties' perceptions concerning present threats and the potential for security and benefit sharing that mitigates them. We show that the Surgutneftegaz oil company management's approach, based on principles of benefit sharing, seeks to provide economic security in the form of jobs, material support, and infrastructure to ensure development in the indigenous community. In contrast, the indigenous people of Numto emphasise cultural and environmental security, meaning opportunities to maintain their traditional way of life, e.g. fishing and reindeer herding. The study suggests that a focus on different perspectives and on different aspects of security provides a better understanding of complex interactions between oil companies and indigenous peoples in areas affected by industrialisation and modernisation.

The paper also focuses on the reception of benefit-sharing arrangements by indigenous residents of Numto Nature Park, based on their understanding of cultural and environmental impacts. We draw on the literature on benefit sharing as well as the concept of cultural security to shed light on these perceptions. We start the paper with a description of our theoretical approach, then proceed to give a brief description of the conflict's context and our empirical study. In the two sections that follow, the views and perceptions of both the company management and the indigenous reindeer herders that inhabit Numto Park are analysed. In the discussion section, we highlight important differences in the parties' perspectives on development and benefit sharing, which shape their prioritisation of different types of security.

\section{Benefit sharing: theoretical perspectives}

Security in the Arctic is a complex phenomenon that involves not only peace between countries, but also human security, including security for the indigenous peoples who inhabit land often shared with extractive industries. ${ }^{8-10}$ Indigenous peoples' security is a multifaceted concept that encompasses not only economic and infrastructural aspects of everyday life, but also the security of their traditional culture and environment. ${ }^{11}$ Human security looks at peoples' or communities' perceptions of security, which does not necessarily correspond with objective measures of risk. ${ }^{12}$ Indigenous peoples' security and environmental security are closely related, as traditional food harvesting and reindeer herding have economic, symbolic and spiritual value. Social cohesion, identity and overall wellbeing depend on the health of the ecosystems where indigenous people exercise their traditional practices. In this case study, security is related to the Forest Nenets' subjective perception of the consequences of expanding oil development. From the perspective of many Arctic indigenous communities, extractive industries put both environmental and human security at risk when they practice extraction on traditional lands, which can disrupt harvesting and herding activities. ${ }^{13}$ 
Benefit sharing has become the prevalent model of managing relations between extractive industries and indigenous peoples in the Arctic. It is an arrangement defined as the distribution back to communities of monetary and non-monetary benefits generated by the revenue companies procure through resource extraction. ${ }^{14}$ Companies try to avoid reputational risks by providing funds to those affected by extraction activities, thus contributing to their economic security. The provision of these benefits may be direct or indirect and may include the local as well as national levels (e.g. Alaska Permanent Fund, Impact Benefit Agreements (IPAs) in Canada, aboriginal agreements in Australia, Bolivia and other countries). ${ }^{15}$ Indirect benefits are those provided to local communities through taxation; direct benefits comprise funds required by legislation or set out in partnership agreements among the company, the state and indigenous communities. Partnership agreements often include charitable giving, sponsorship and trickle-down benefits such as the construction of social infrastructure and the creation of jobs locally for indigenous people. ${ }^{16}$

Benefit sharing agreements between oil companies and indigenous peoples are arranged differently in different regions of the Russian North: in NAO and Irkutsk Oblast they are negotiated between the company and indigenous enterprise directly, whereas in Yamal Autonomous Okrug, the state plays a crucial role in setting up such agreements. ${ }^{17}$ As we describe in detail below, these differences in the negotiation and delivery of benefit sharing, as well as different understandings and prioritisations of ecological and cultural impacts, contribute to very different relations between indigenous peoples and extractive industries, ranging from confrontation to co-existence and/or co-ignorance. ${ }^{18}$

In our earlier studies, we distinguished between three delivery modes of benefit sharing: paternalism, company-centred social responsibility (CCSR) and partnerships. We based our research on case studies conducted in NAO, Irkutsk Oblast, Komi Republic and on Sakhalin Island. ${ }^{19}$ The form of benefit sharing depends on the regional context, legislation, corporate policies, regional governments' agendas, empowerment of indigenous peoples and other considerations. ${ }^{20}$ The paternalistic mode of development in Russia, a remnant of the Soviet past, results in powerful actors such as the state or a company dominating the setup and implementation of benefit-sharing arrangements; indigenous people have relatively limited control. This was the approach observed in NAO in the early 2000s, for example. Between 2012 and 2018, indigenous people were empowered through negotiations with oil companies and relationships became less paternalistic. ${ }^{21}$ CCSR is an arrangement whereby companies adopt standards required by legislation, lending banks, governmental recommendations and shareholders' demands and address community needs to the extent necessary for purposes of public relations. This arrangement has been employed in many regions of Russia, including the Komi Republic and Irkutsk Oblast. Finally, the partnership mode, observed on Sakhalin Island, entails a tripartite partnership between the company, state and indigenous people. Although partners have different levels of power and authority, this approach guarantees participation 


\section{Dr. Maria Tysiachniouk and Dr. Irina Olimpieva}

of indigenous people in the distribution of benefits from the company to the indigenous community. ${ }^{22}$ All these modes of benefit sharing have specific advantages and disadvantages for indigenous people, as well as different implications for cultural and environmental security.

In this paper, we apply this theoretical approach to an analysis of benefit sharing arrangements in Numto Nature Park, where we identify a mix of CCSR and paternalistic approaches. In $\mathrm{KhMAO}$, comprehensive regional legislation aims to preserve indigenous cultures and traditional lifestyles. It facilitates the development of traditional economic activities and creates conditions for the preservation of indigenous cultures and traditional ways of life. To fulfill these tasks, regulations on indigenous peoples in KhMAO were adopted in 1989, titled "On the Status of Territories for Priority Natural Resource Management", followed in 2001 by the Federal law "On Territories of Traditional Natural Resource Use (TRN) by Indigenous Minorities of the North, Siberia and Far East of the Russian Federation". ${ }^{23}$ The aim of these laws was to guarantee traditional resource use, which implies maintaining cultural traditions and traditional food harvesting for the Forest Nenets, Khanty and Mansy peoples. ${ }^{24}$ In 2006, a new law was enacted titled "Regional TRNs in the Khanty-Mansy Autonomous Okrug", which specifies that a company need only obtain consent from an indigenous enterprise and pay compensation if a TRN is on the official register. ${ }^{25}$

One of the assumptions behind these legal frameworks is that fair and equitable benefit sharing from resource extraction along with a favorable regulatory framework can promote the economic wellbeing of indigenous people by providing material benefits, social infrastructure and local employment. However, despite a favorable legal/regulatory framework, conflicts continue to occur between companies and indigenous people. The case of Numto Park will demonstrate this. Indeed, the extent to which the companies' benefit sharing strategies support cultural integrity remains questionable. This paper will shed light on the disparate views on development, benefits and threats held by the oil company and the park's indigenous people.

\section{Numto Nature Park and Numto Village: History of the Conflict}

Numto Nature Park totals more than half a million hectares (about 7,218 square $\mathrm{km})$. It is situated in the Beloyarsky district of KhMAO on the border of the YamaloNAO in the centre of the West Siberian Plain. Established in 1997, the park aims to preserve the unique natural complex of local wetlands and protect the traditional way of life and culture of the Forest Nenets and Khanti peoples, who have lived in the area for centuries, and who account for the largest proportion of the indigenous population in the park. The park's zoning, approved by the regional government in 2001, established four functional zones and several protected areas to regulate different activities: natural ecosystems protection, subsistence activities (e.g. reindeer herding, hunting and fishing), tourism, and oil extraction. Areas where economic use is allowed make up almost $63 \%$ of the park's territory. 
Within the park's boundaries, indigenous people are involved in reindeer herding, fishing, hunting and gathering; additionally, some of them work for the park or for Surgutneftegaz. The Khanti people live in the western part of the park; they have six registered TRNs around their reindeer herding and fishing grounds. They have standard agreements with Surgutneftegaz on socio-economic cooperation and compensation for damage. Forest Nenets people, who live in the eastern part of the park, have neither formal registration of their land nor a standard agreement with the oil company. They receive financial aid through the Beloyarsky district administration.

With a population of 212 , the village of Numto, the central reindeer herding settlement in the park, is located near the sacred Lake Numto. The lake is worshiped by local people as a "living god", and the village's main religious ceremonies take place there. ${ }^{26}$ Transportation to the village is poor. In winter, villagers use snowmobiles to get to the main road where bus service is offered; in summer, helicopters are the main means of transportation. The settlement lacks a constant supply of electricity and running water. The nearest hospital, childcare, and educational institutions are located approximately 60 kilometres away in Kazym, the district's administrative centre. Food supplies and household goods are available in the village shop.

The Numto settlement's economy is traditional and informal. Reindeer herding remains the basis of household economic activity. Significantly, the responsibilities associated with this occupation, as well as the lack of ready access to stores, keep the rate of alcoholism low. The overwhelming majority of the settlement's residents are spread around the park's territory and live in camps adjacent to pastures within an 80-kilometre radius of the village; only 20 people live in the village year-round. Living in camps without electricity, water or sewage pipelines remains a customary way of life, even though herders increasingly use snowmobiles and mobile phones. According to the local people and experts, the settlement is the last remaining bulwark of the authentic Nenets culture in KhMAO.

$\mathrm{KhMAO}$ is a leading oil-producing region, producing over $50 \%$ of all the oil extracted in Russia. The regional budget is characterised by a direct dependence on oil production. ${ }^{27}$ Surgutneftegaz is the second largest extractive company in the area, producing $21.2 \%$ of the total oil extracted (after ROSNEFT with $40.1 \%$, and ahead of LUKOIL with $18.6 \%$ ). Unlike the other big oil companies, which are registered in Moscow, Surgutneftegaz is registered in KhMAO. ${ }^{28}$ It is the region's biggest taxpayer, accounting for $40 \%$ of revenues in the regional budget. ${ }^{29}$

In 1999, Surgutneftegaz acquired a license for the geological study and assessment of fossil fuel reserves in an area that overlapped with the Numto Nature Park. ${ }^{30}$ Since then, Surgutneftegaz has intensively developed oil fields on the eight concessions it holds in Numto Park, where oil extraction is allowed based on 2001 zoning laws. One of the licenses for drilling was in the area around Lake Numto, but the regional administration denied access to this territory, as it contains protected wetlands. The most recent turn of events came in 2012, when the company again claimed that it was essential to develop the oil fields in the protected areas of the park 


\section{Dr. Maria Tysiachniouk and Dr. Irina Olimpieva}

and demanded rezoning that would make those areas available for industrial exploration. KhMAO's new administration was very interested in expanding oil production because the decline in oil revenues over the previous five years had negatively affected the regional budget. The company's desire for rezoning and the administration's interest in further production sparked a conflict between Surgutneftegaz and the Forest Nenets living in the park.

\section{Methodology and data collection}

The paper combines fieldwork with an analysis of documents. Empirical data includes semi-structured interviews with Surgutneftegaz's management, indigenous residents within the park, and representatives of the regional administration, the district administration and civil society organisations. The interviews took place during field expeditions in August 2014 in the cities of Surgut, Khanty-Mansiisk and Beloyarski, in the settlement of Numto and at Surgutneftegaz's booster compressor station. In December 2014, interviews and participant observations were carried out in 29 indigenous family camps located within the park. Participant observation also took place at the stakeholder meeting in May 2015 in Khanty-Mansiisk, and at the public hearings held in February 2016 in Beloyarski as part of the environmental impact assessment of the rezoning proposal.

The list of informants includes: state authorities in KhMAO $(n=3)$, municipal officials in Beloyarski $(n=8)$, the administration of Numto Nature Park $(n=3)$, managers at Surgutneftegaz $(n=13)$, expert biologists $(n=4)$, indigenous leaders $(n=2)$, representatives of civil society organisations $(n=6)$ and indigenous people in Numto Park $(n=12)$ (see Appendix 1). The interviews were transcribed and coded to analyse the stakeholders' interests.

The study analysed legal documents provided by Wetlands International, the regional administration and OAO Surgutneftegaz, GIS mapping of the territories of the park as well as official petitions and appeals by different parties to organisations and institutions at both the regional and federal levels. The research also drew on media publications, materials on the historical background of the park and economic and social statistics on the region.

The analysis focuses on two major conflicting parties: the company management and Numto Park's indigenous population. The interviews revealed different perceptions of threats and benefits, which can be seen as fundamental to and characteristic of the parties.

\section{Results}

5.1 The perspective of the company's management: the benefit-sharing approach Surgutneftegaz positions itself as an environmentally and socially responsible company, and it is highly rated by WWF-Russia. ${ }^{31}$ The company has tried to build a 
dialogue with indigenous people on the basis of a multi-level system of benefit sharing, which targets not only the region as a whole, but also the specific territories where oil extraction takes place. In addition to being the biggest taxpayer, Surgutneftegaz provides economic assistance to the region through socio-economic agreements and implementing social programmes. Since 2003, such agreements have been signed on a yearly basis between the region's governor and the head of the company. ${ }^{32}$

In the districts (rayoni), the company provides a level of material and financial aid in keeping with the amount of oil extracted in a particular territory. As one interviewee noted:

The volume of financial aid depends on [the volume of oil] extraction. That is, if the territory allows extraction, and if extraction is carried out, this means that Surgutneftegaz makes a profit, and it shares this profit ... We gain [something] on this territory and [as a result] share profits. If we don't gain anything, there is nothing we can share. ${ }^{33}$

The interdependency between the volume of economic benefits and the volume of extraction creates a situation in which the district administration is highly incentivised to expand oil extraction. Within these aid packages, there is no mechanism to provide compensation for damages that are a result of an expansion of extraction activities. Instead, funds are channeled through the district administration, which makes decisions on distributing funds to local communities throughout the district. The administration occasionally decides to share funds provided by Surgutneftegaz with communities situated outside of Numto Park that are not affected.

Indigenous people with registered TRNs receive compensation for loss of use on the basis of individual standard agreements. The peculiarity of this case is that impacts are not measured, therefore compensation is not scaled dependent on how much loss of use has incurred; severely and lightly affected indigenous households receive the same amount of goods. Despite this, money paid is framed as compensation and not financial aid. ${ }^{34}$

As mentioned above, only six households in Numto have TRNs; the rest use pastures in accordance with oral agreements with each other. As a result, with the company's permission, the district administration in Beloyarski distributes funds to unregistered pastures, and frames it as financial aid. Each year, the company gives around 20 million rubles in aid to the Beloyarski district. According to a representative of the Beloyarski district administration, two-thirds of this money goes to the inhabitants of Numto village. Although this aid is based on an assumption of impacts and potential damages, in Numto, it is described as "financial aid" rather than compensation. The result is that although some households receive "compensation" and others receive "financial aid", all payments derive from funding provided by the oil company and are based on loss of access to pasture land rather than severity of impact.

Funding from Surgutneftegaz makes up for shortfalls in the local districts, which receive insufficient funds from the regional government. For instance, with the company's help, a medical station was built in Numto and a local store has opened where 


\section{Dr. Maria Tysiachniouk and Dr. Irina Olimpieva}

villagers can buy needed goods. In addition, two or three houses are built every year in the village to allow reindeer herders to retire or to stay in the village when necessary. ${ }^{35}$ The houses are for those who would otherwise be eligible for state-sponsored flats; the company is therefore directly stepping in for a gap in state services.

There are also trickle-down benefits, one being employment for indigenous people at the company. Each year, the company reserves five pipeline monitoring positions for indigenous inhabitants of the district. In 2014, three indigenous people from Numto worked at the company. Additionally, the company provides all means of transport and roads in the territory. As a result, the region's inhabitants recognise Surgutneftegaz's role in fulfilling a number of crucial state functions:

Surgutneftegaz pays for the helicopters. [...] They have transported children to Numto in the spring, and brought them back to school in the autumn. They have provided transportation for them both ways during the winter break. Now we are making plans for 2014 as they are supplying us with a prefabricated building to build a community centre in Numto village. We have reached the point that Surgutneftegaz provides the village with up to $100 \mathrm{~m} 3$ of firewood for pensioners ... ${ }^{36}$

Additionally, the company pays for the technical education of several students from the village, provides indigenous households with some lumber and two barrels of gasoline (the yearly need for gasoline per family is around 12-15 barrels), and delivers firewood to retired people. The company sponsors festivities and competitions organised annually on Reindeer Herders' Day, provides support and transportation in extreme situations and subsidises the traditional village economy, for example, by purchasing reindeer meat, berries and mushrooms from villagers as a form of income generation. Furthermore, according to the agreement between Surgutneftegaz and the Numto park administration, the company provides the latter with transportation, technical support, communication, navigation and even support for scientific research.

In interviews, representatives of Surgutneftegaz point to the company's social responsibility by emphasising that it ensures the economic and infrastructural security of Numto village's inhabitants. The interviewees highlight that Surgutneftegaz differs from other oil companies working in the region; they emphasise that as a local company, it spends its own income to support indigenous people, whereas other companies either use funds procured from international organisations (as is the case with LUKOIL) or state money (like state-owned ROSNEFT).

Company managers consider the ecological risks related to oil extraction in the park as a necessary evil that one must come to terms with. At the same time, they repeatedly highlight the attention that the company pays to ecologically safe extraction methods based on the latest technologies and its intensive efforts to prevent and clean up oil spills. Moreover, in collaboration with the villagers of Numto, the company has developed a guide for company workers that sets out the rules of conduct on sacred territories. 
Overall, from the company's perspective, the economic benefits received by indigenous people due to the expansion of oil extraction considerably outweigh the related ecological and cultural risks and possible negative consequences for the villagers' traditional way of life. Infrastructural improvements, including the uninterrupted provision of electricity and the building of roads, are considered the principal need. The company's representatives assume that that the park's population values and prioritises these forms of development:

The standard of living here is [low], they aren't even able to have fridges since they do not have a constant supply of electricity; they also cannot watch television. In particular, in regards to electricity, outages are frequent and the supply lasts only for a few hours. [...] This is why I think that they would want a continuous supply of water, around the clock, all year round, and of electricity as well; this is essential. ${ }^{37}$

The company's representatives perceive the traditional lifestyle of reindeer herders as outmoded and as having no economic potential. Overall, the company's management has a paternalistic attitude towards the villagers, who, they argue, are in constant need of material and infrastructural support from the company:

... the times are different. [...], it is impossible to sustain yourself with the traditional way of life. Nobody needs it anymore. This fish he cannot sell; fresh fish he can sell but he will only bring in 50-100 kg. He cannot catch more than that. He will spend so much money on petrol for his snowmobile that it will not be profitable for him. This is why I say that he does not gain anything from traditional activities ... ${ }^{38}$

From the managers' point of view, threats to Forest Nenets' traditional lifestyle are not related to the company's actions, but are the result of state-led modernisation processes and the transition to a market economy. At the same time, they accuse the government of paying insufficient attention to the interests of indigenous people. Indeed, the company perceives itself as fulfilling the role of the state in supporting the traditional lifestyle of indigenous people:

The state does not support the indigenous people at all. Agriculture has fallen apart; they have nowhere to sell reindeer meat and fur prices have dropped. In the past, there was a demand for sable and mink, but now the animals are raised in cages. Who needs wild furs today? This is why the prices for them have dropped, and the traditional lifestyle has begun to deteriorate. ${ }^{39}$

The perception that the indigenous people in Numto are incapable of maintaining their traditional lifestyle without external help constructs a relationship between the villagers and the company as one of economic dependency and even extortion by the villagers. As one manager notes, "[they're] loafers, they just want to have everything for free." ${ }^{40}$

The benefit-sharing approach underpinning the company's policy towards indigenous people, combined with a serious lack of state money, has led to a situation where the company has become the major provider of goods and services, and serves 


\section{Dr. Maria Tysiachniouk and Dr. Irina Olimpieva}

as a substitute for the state in sustaining life for the inhabitants of Numto Park. The image of the park inhabitants as economically dependent and "undermodernised" makes economic and infrastructural security issues of paramount importance to the company's management when arguing for expanding oil extraction on park territory.

\section{2 Numto inhabitants' perspective: benefits and threats of oil development}

Numto Park's inhabitants have contradictory and ambiguous perceptions of Surgutneftegaz, formed along two parallel dimensions. The first dimension involves the material and infrastructural support and compensatory policy of the company. On the one hand, the villagers are attracted by the goods offered and are happy to receive snowmobiles and mobile phones from the company. At the same time, the residents of Numto are used to their semi-nomadic lifestyle; the urban environment scares them. Using public transportation "tires them more than hours of walking." ${ }^{41}$ Since most of the indigenous people have spent their lives living in a camp and managing their time independently, it is very difficult for them to become accustomed to strict working hours. The indigenous people from Numto Nature Park who work in shifts for Surgutneftegaz while continuing reindeer herding have some qualms about working for the company. The fear of having to renounce their traditional way of life dominates their narratives. This is especially true for people who reindeer herd on overgrazed collective pastures where additional extraction of land would be particularly detrimental:

If they build oil rigs, then we ... will have nowhere to go. For example, I cannot live in the city; I need to live with the reindeer herd, to finish my life there. And in the city? In the city, we will be done for. ${ }^{42}$

As mentioned earlier, Surgutneftegaz makes up for the lack of state funding in many ways, providing welfare for the inhabitants of Numto Park and solving problems that in Soviet times were the state's sole responsibility. For this reason, the reindeer herders take for granted any help from the company. Interview participants did not mention the company's economic or infrastructural assistance unless asked a specific question about it. The extent of the aid given does not usually match people's expectations, especially when compared to the more generous compensation paid by other companies such as LUKOIL and ROSNEFT. The informants often complained about the unfairness of the system, where the Beloyarski region's administration distributes the aid, because they believe that they do not receive the entirety of the aid allocated for them. They are also angry that the aid is taxed.

The second dimension of the company's image relates to environmental and cultural issues. Here residents perceive the company as a conqueror that has harmed nature and disrupted their familiar way of life. Neither the company's assertions that it is local nor its various benefit sharing programmes help change the perception that alien oilmen have destroyed the people's lands:

When the oilmen weren't here, there were ducks and berries, and now there is nothing, not even ducks, very little. ${ }^{43}$ 
The reason for these negative attitudes lies in the high ecological and cultural risks of industrial expansion. The possibility of oil spills and pollution of water reservoirs is the biggest source of anxiety among the villagers, as these incidents could lead to the extinction of fish and animals that constitute a crucial part of the natural economy on which the households rely. The majority of Numto reindeer herders have relatives in Surgut district, where indigenous people have experienced the negative impacts of oil development. They feel that the impacts will be even more severe in Numto Nature Park. The informants repeatedly express the worry that oil extraction and the industrial infrastructure accompanying it might cause problems for reindeer herding:

A reindeer is afraid of machines, and of people also; it only comes to its master. Deer are afraid of other people, they are semi-wild. ${ }^{44}$

When we walk, the reindeer know us, that we are theirs; they are not very afraid. But they can always recognise the Russian smell and run away ... The people who work there smell of oil; they are impregnated with the machine [smell]. So they [the reindeer] get scared. ${ }^{45}$

Although reindeer husbandry is not as important in terms of economic profitability, engaging in reindeer herding is of primary importance for the preservation of the culture and traditional way of life of Numto's inhabitants. It is always brought up as a factor that restrains alcoholism, which is a problem that indigenous people face across the Russian North and around the world: ${ }^{46}$

... We don't have many heavy drinkers. Sometimes it happens that someone drinks for a week, but they know that they have to go home and graze their deer. ${ }^{47}$

Numto's inhabitants are very skeptical about any assertions made by the company's management regarding the minimisation of ecological risks. Informal networks bring news about negative experiences in other districts of KhMAO that have suffered heavily from oil companies' irresponsible behaviour. The indigenous people's mistrust towards the company is made worse by the disrespect that the company's workers show towards them:

An indigenous man - [to them] is necessarily an alcoholic and illiterate" ... "with the arrival of this company we have acquired nationality [...] we all have become Khants, alcoholics, illiterate, rolling in the dust. ${ }^{48}$

Numto Park's indigenous inhabitants are equally concerned about preserving their traditional culture, which until now has survived due to the relative isolation of the village and the settlement's traditional enclave economy. This being the case, improving the village's accessibility, in particular the building of a new road, as well as providing a constant electricity supply, have not been welcomed as warmly by the villagers as Surgutneftegaz's representatives might have imagined:

What's the road for? If they make the road, they will come here, hunt, there will be a lot of poachers. It is better to be inaccessible. ${ }^{49}$ 


\section{Dr. Maria Tysiachniouk and Dr. Irina Olimpieva}

The company's many intrusions into sacred territories are also considered a serious threat to Nenets culture by locals and are seen as a sign of disrespect for indigenous traditions. The villagers do not believe the company's promises that it will create a protection zone around Numto Lake, a key sacred location in the park.

Interviews with the park's indigenous reindeer herders revealed contradictory views of Surgutneftegaz. While they consider the company's contribution in providing economic benefits as positive, this does not receive much attention or appreciation in the villagers' accounts. They perceive the material aid provided by Surgutneftegaz as either mandatory compensation or as paternalistic care that they are due as citizens. Central in the narratives of the park's inhabitants are concerns about the potential ecological harm caused by the company's expansion into park territory and the threats to their traditional way of life. In this light, a strengthening of compensatory practices by the company will not help change its image as an outside invader. Despite the fact that some goods provided by the company have been embraced by Numto Park's indigenous inhabitants, problems of ecological and cultural security remain central to them.

\section{Analysis and Discussion}

\subsection{Benefit-sharing modes and regulations}

Building relationships in line with fair and equitable benefit sharing is not a straightforward task. Partnership-mode benefit sharing, perceived by researchers as participatory and empowering, is considered an ideal model for interaction between companies and indigenous communities. ${ }^{50}$ Notably, partnership-mode approaches apply Free Prior and Informed Consent (FPIC) to benefit sharing arrangements so that indigenous peoples themselves decide which projects will be supported with company funding. ${ }^{51}$ This can result in higher levels of engagement by indigenous communities, as seen for example on Sakhalin Island, despite lower sums of money being allocated here than in West Siberia.

The Numto case study shows that relations between the company and indigenous population are more confrontational than cooperative. Although the money allocated is framed as financial aid within the formal cooperation agreements in place in the Beloyarski district, it is in fact of a compensatory nature due to reduced access to pastures. As more land is allocated for development activities, more money is offered through redistribution mechanisms. This is consistent with the managerial literature, in which the benefit-sharing process is mostly viewed as compensation, meaning a flow of resources to those who grant access to a particular resource from those who provide rewards for its use.$^{52}$ Framing these funds as financial aid allows the Beloyarski administration to share the money allocated to Numto with other villages in the district. The Numto residents perceive these funds as compensation, while residents of the other villages, which are not affected by development but nevertheless receive funds, see this money as benefit sharing. 
As this example illustrates, consistent with several other cases in Russia, there is no clear delineation between social-economic cooperation agreements and compensation. In NAO prior to 2011, for example, companies and reindeer herding enterprises concluded socio-economic agreements which were based on negotiations between companies and indigenous enterprises. When reindeer herders started using the federal methodology for calculating damage, however, they realised that requesting compensation for loss of land would result in more funding. The majority of reindeer herding enterprises switched to compensation instead. ${ }^{53}$ Some anthropological scholars claim that a 'compensation culture' has emerged because people focus on the damage caused by project activities rather than joining forces to minimise and mitigate negative effects through resource management. ${ }^{54,55}$

In contrast, the benefit sharing arrangements between Surgutneftegaz and Nenets in Numto Nature Park represent a combination of paternalism and CCSR, both of which involve compensation for loss of use. CCSR views indigenous people as 'stakeholders' who on the one hand are affected by a corporation's operations, and on the other have an impact on its performance..$^{56}$ For example, on Sakhalin Island and in the Urkutsk region of Russian Siberia, companies receive loans from investment banks only when they demonstrate that they are working closely with indigenous peoples. Banks monitor interaction between indigenous peoples and companies, and complaints are reviewed by third party assessors. ${ }^{57}$ There are no such mechanisms in place in the Khanty-Mansy region; this study shows that the company's operations affect indigenous people in Numto Nature Park, but their voice is not influential in shaping operations.

There are different drivers of reform in corporate practice. One is implementation of regulations at the international, national, or regional/district level. At the international level, Russia has not ratified ILO Convention No. 169 and abstained from voting to adopt the 2007 UN Declaration on the Rights of Indigenous Peoples; these would possibly improve company-indigenous relations. Although Russia signed the Convention on Biodiversity, in practice it has not implemented the Akwé: Kon Voluntary Guidelines for the Conduct of Cultural, Environmental and Social Impact Assessment regarding development on indigenous territories. In domestic law, irregularities in the land entitlements of indigenous minorities and in traditional nature use allow contradictory interpretations of land-use rights by the companies and indigenous communities in many regions. In the Russian North, a complex legislative environment has allowed the region to implement its own rules, ${ }^{58}$ yet has also created barriers to the effective engagement of indigenous peoples in extractive-sector developments. ${ }^{59}$ Khanty-Mansy Okrug, where regional rules and regulations have filled the gaps in federal legislation, and companies including Surgutneftegaz follow them, is an exception.

\subsection{The causes of discrepancies in security priorities}

The study of the rezoning conflict in Numto Park has revealed considerable discrepancies in the perceptions of security priorities between managers of Surgutneftegaz, 


\section{Dr. Maria Tysiachniouk and Dr. Irina Olimpieva}

who work with indigenous people, and the indigenous people themselves. The managerial perspective emphasises economic and infrastructural security, while indigenous people highlight ecological and cultural security. The causes of these discrepancies lie in the lack of shared views about the general impact of industrial projects on indigenous communities. While the conflicting parties anticipate expansion of oil extraction into new territories, with concomitant modernisation, they differ dramatically in how they see this development affecting indigenous people in the area. Representatives from business perceive modernisation as a positive process that follows directly from the development of a market economy and that will ultimately be beneficial for indigenous communities. An argument frequently voiced by the company's management is that the quality of life of indigenous people in areas with oil production is higher than in areas that lack oil resources. According to them, thanks to the oil companies, roads have been built, the social infrastructure has improved and financial assistance has been provided to the local people. Representatives of regional and district administrations largely share this position:

There would not be any problems for the village; in terms of development, "civilization", it would take big steps forwards. For the population that lives there, it would become an oasis ... because a road would be built, access to electricity would be ensured and the further development of the entire village [would be guaranteed]. Today the youth are studying somewhere, and later they would be able to work and receive a stable wage. ${ }^{60}$

The company's representatives realise that development of oil extraction in the region affects the environment and ruins the indigenous people's traditional way of life:

$\ldots$ it is true that we are "squeezing them out"; we are bringing in civilization, and there is no way around it for them. ${ }^{61}$ However, they consider it a necessary price to pay for modernisation, which is considered advantageous: “.. it is impossible to stop the progress, and most importantly it leads to a much better life." ${ }^{\prime 2}$

Local inhabitants have a completely different perspective. Much like the representatives of Surgutneftegaz, villagers (as well as NGO representatives) realise that sooner or later they will have to resign themselves to the arrival of the oil companies. Most of all, they dread the imminent destruction of their traditional lifestyle. Development of the park territories for the purposes of oil extraction thus prompts only negative associations. Indigenous interview participants often told stories about and gave examples of harm caused by oil companies to the Khanty indigenous people in Surgut district where many of their relatives live. Most stories related to fish stocks declining and fish poisoning.

Thus, a discrepancy in perceptions of threats and security concerns between management and the indigenous population undermines the effectiveness of the benefit sharing arrangement developed by Surgutneftegaz, which has sought to build a dialogue with the residents of Numto Park. 


\subsection{Benefit sharing and the importance of human security}

In implementing benefit sharing, it is important to distinguish between distributive and participatory aspects of the approach. ${ }^{63}$ The former implies sharing material and non-material benefits and providing aid to indigenous people that offsets negative impacts on nature and traditional culture; the latter means engaging indigenous people in resource management and opportunities for them to influence the company's performance. Effective participation implies well-developed mechanisms for representing one's interests as well as strong 'bargaining power', that is, the ability to force extracting companies to listen to what indigenous people have to say. If interaction is to be successful, a balance must be struck between compensation and participation. While distributive mechanisms are crucial, fair and equitable benefit sharing arrangements are not complete without the participation of indigenous people in the process of making decisions that directly affect their environment, culture and traditional way of life. The time that company managers spend at public meetings in Numto is usually limited by the time that the helicopter can wait, with the result that indigenous people feel that they do not have enough time to express their views.

In this light, one additional reason that can be cited for Surgutneftegaz's and the Numto villagers' different perceptions is the lack of a participatory dimension in their benefit-sharing arrangements. In 2016, an Environmental Impact Assessment (EIA) was conducted by the firm Ecomax, and public hearings were held in the city of Beloyarsk. Simultaneously, Greenpeace organized a worldwide campaign to save Numto Nature Park and challenged the quality of the EIA. Meanwhile, the company has continued to pursue its development agenda with no mechanism for indigenous people to voice concerns or influence the process. ${ }^{64}$ It is easier and economically advantageous for the company to simply "pay off" indigenous residents of the park with material goods than to develop complicated mechanisms that would allow them to participate and provide them with opportunities to temper the ecological and cultural risks involved. The company's growing influence on the region's economy in recent years exacerbates the existent inequality between it and indigenous actors in negotiations about the future of land use in Numto Park. Despite sympathizing with the grievances of the indigenous people, the national park's administration depends on Surgutneftegaz's money for park maintenance and infrastructure, so they do not actively support indigenous protests. As a result, dialogue between indigenous stakeholders and the company has become a mere formality.

The local and institutional context also accounts for the marginal involvement of indigenous people in dialogues with the company. When civil society is weak and the paternalist role of state structures is maintained, what is known as the "social license to operate"-i.e. the local community's approval for the companies' actions - is in fact granted by the state. ${ }^{65}$ Regional and local administration support oil extraction in the region and thus do not question the existing imbalance between 


\section{Dr. Maria Tysiachniouk and Dr. Irina Olimpieva}

the compensatory and participatory aspects of corporate-indigenous relations. They share the company's prioritisation of economic security and ignore concerns the indigenous inhabitants have expressed regarding the company's negative impact on the environment in Numto Park and the traditional culture of its inhabitants. These attitudes have only served to increase the indigenous people's economic dependence, which is the result of an exchange of modern goods for loyalty to the company's industrial activity.

\section{Concluding remarks}

Our research demonstrates radical differences in perceptions of threats and security between the Surgutneftegaz oil company and the indigenous population of Numto Park concerning the expansion of oil extraction. The company's perspective emphasises economic and infrastructural benefits, while the indigenous people emphasise ecological and cultural security. The study shows that these differences in perception reflect the imbalance between the distributive and participatory aspects of the parties' benefit-sharing arrangements. Moreover, our analysis demonstrates that discrepant perceptions are rooted in more general views on the impact that modernisation has on the traditional way of life of indigenous communities. While company managers emphasise the benefits of industrial projects for the indigenous population, such as employment, urban-type infrastructure and improved services, the reindeer herders see the extension of oil extraction as having mostly negative consequences. Therefore, there is a discrepancy between those who design benefit-sharing arrangements and those who are supposed to be the beneficiaries. Indigenous people would prefer the preservation of traditional life and even isolation from the industrial world to the benefits offered by the company. Yet, at the same time, the indigenous people do not refuse material compensation from the company, as it is expected, in keeping with the neo-paternalistic relationship between oil companies and local communities in the Russian North.

In practical terms, divergent views on the ecological and cultural risks that stem from oil extraction help to explain the origin of the confrontation between indigenous people and the oil companies, and why Increasing economic and infrastructural benefits does not reduce the lack of trust between them. Although an improved economic and infrastructural situation is presented by the management (and supported by the regional administration) as being in the mutual interest of indigenous communities and business, it in fact represents a 'business-centred' perspective on the development of indigenous lands; one that is aligned with the CCSR mode of benefit sharing. This study suggests that the benefit-sharing policies of oil companies would do well to include a community-centred perspective that emphasises environmental and cultural safety. The first step would be to introduce ethnological assessments of the oil industry's impact on the focal region. 


\section{Acknowledgements}

This research was supported by the Fulbright Arctic Initiative; the senior research co-found fellowship at Durham University, funded by the European Union, Institute of Advanced Study (IAS), and the Department of Education; support by the NWO, the Netherlands Organization for Scientific Research, Arctic Program ("Developing benefit sharing standards in the Arctic", No. 866.15.203), and the Finnish Academy Arctic Program ("Oil Production Networks in the Russian Arctic", No. 286791).

\section{Notes}

1. Southcott, Chris, ed., "Northern Communities Working Together: The Social Economy of Canada's North." University of Toronto Press, (2015).

2. Diamond, Stanley "In search of the primitive: A critique of civilization." Routledge, (2017).

3. Stammler, Florian and Vladislav Peskov, "Building a 'culture of dialogue' among stakeholders in North-West Russian oil extraction" in Europe-Asia Studies 60, 5(2008) pp. 831-849.

4. Henry, Laura A., Nysten-Haarala, Soili, Tulaeva, Svetlana, and Maria Tysiachniouk, "Corporate Social Responsibility and the Oil Industry in the Russian Arctic: Global Norms and NeoPaternalism” in Europe-Asia Studies, 68, 8(2016) pp. 1340-1368.

5. Roon, Tatiana, “Globalization of Sakhalin's Oil Industry: Partnership or Conflict? A Reflection on the Etnologicheskaia Ekspertiza", in Wilson, E. and Stammler F. (eds.) Special issue of Sibirica: the Interdisciplinary fournal of Siberian Studies 5 (2)(2006) pp. 103-114; Wilson, Emma, "Conflict or Compromise? Traditional Natural Resource Use and Oil Exploitation in Northeastern Sakhalin, Nogliki District" in Murakami, T. (ed.) Russian Regions: Economic Growth and Environment, Slavic Research Center, Hokkaido University, Occasional Papers 71. Sapporo (1999) pp. 273-299; Wilson, Emma, "What is the Social License to Operate? Local Perceptions of Oil and Gas Projects in Russia's Komi Republic and Sakhalin Island” in The Extractive Industries and Society 3 (2016) pp. 73-81.

6. West, Paige, Igoe, James, and Dan Brockington, "Parks and Peoples: the Social impact of protected areas" in Annual Review of Anthropology, 35 (2006) pp. 251-277; West, Paige. Conservation is our government now: the politics of ecology in Papua New Guinea. Duke University Press, (2006). Koljur, Louren, "Why Russia's Indigenous People Are Wary Of National Parks" in World News, Arctic Deeply, (2017) https://www.huffingtonpost.com/entry/why-russiasindigenous-people-are-wary-of-national-parks_us_5925e05ae4b061d8f81ebf5a, accessed 05.27.2018.

7. "Bikin National Park Cares of Nature and People" https://www.wwf.ru/resources/news/article/ eng/15086, accessed 10.05.2017.

8. Exner-Pirot, Heather, "What is the Arctic a Case of? The Arctic as a Regional Environmental Security Complex and the Implications for Policy" in The Polar fournal 3.1 (2013) pp. 120-135.

9. Cocklin, Chris, "Water and "Cultural Security" in "Human Security and the Environment: International Comparisons (2002): 154-176.

10. Stuvøy, Kirsti, "Human Security, Oil and People: An Actor-Based Security Analysis of the Impacts of Oil Activity in the Komi Republic, Russia" in Fournal of Human Security 7, no. 2 (2011) pp. 5.

11. Power, Elaine M., "Conceptualizing Food Security for Aboriginal People in Canada" in Canadian Fournal of Public Health/Revue Canadienne de Sante'e Publique (2008) pp. 95-97.

12. Hoogensen, Gunhild, Dawn Bazely, Julia Christensen, Andrew Tanentzap, and Evgeny Bojko, "Human Security in the Arctic-Yes, It Is Relevant!." Fournal of Human Security 5, no. 2 (2009): 1. 


\section{Dr. Maria Tysiachniouk and Dr. Irina Olimpieva}

13. Nuttall, Mark. Protecting the Arctic: Indigenous peoples and cultural survival. Routledge, 2005; Cameron, Emilie S. "Securing Indigenous politics: A critique of the vulnerability and adaptation approach to the human dimensions of climate change in the Canadian Arctic." Global environmental change 22.1 (2012): 103-114; O'Faircheallaigh, Ciaran. "Extractive industries and Indigenous peoples: A changing dynamic?.” Fournal of Rural Studies 30 (2013): 20-30; Anthias, Penelope, and Sarah A. Radcliffe. "The ethno-environmental fix and its limits: Indigenous land titling and the production of not-quite-neoliberal natures in Bolivia." Geoforum 64 (2015): 257-269; Holden, William N. "Indigenous peoples and non-ferrous metals mining in the Philippines." The Pacific Review 18.3 (2005): 417-438.

14. Schroeder, Doris, "Benefit Sharing: It's Time for a Definition" in F Med Ethics 33 (2007) pp. 205-209; Fischer, Carolyn, "International Experience with Benefit-Sharing Instruments for Extractive Resources" in Resources for the Future, Washington DC (2007).

15. Kunanayagam, Ramanie and Kathryn Tomlinson, "Indigenous Peoples and Extractive Projects: Success Factors in Compensation and Benefit Sharing Agreements" in September, Oil, Gas $\mathcal{E}$ Energy Law fournal (OGEL) 9, no. 4 (2011).

16. Tysiachniouk, Maria, "Benefit Sharing Arrangements in the Russian North and Alaska" in Russian Analytical Digest, 202 (2017) pp. 2-5.

17. Osipov, Igor A. "Negotiation strategies and agreement-making models in large-scale resource development projects in Yamal, Arctic Russia.” NGPYearbook 2012 (2012): 9-21.

18. Stammler, Florian and Aitalina Ivanova, "Confrontation, Coexistence or Co-ignorance? Negotiating Human-Resource Relations in Two Russian Regions" in The Extractive Industries and Society 3.1 (2016) pp. 60-72.

19. Henry et al. (2016); Tulaeva, Svetlana and Maria Tysiachniouk, "Between Oil and Reindeer" in Fournal of Economic Sociology 18, no. 3 (2017) pp. 70-96; Tysiachniouk, Maria, "Benefit Sharing Arrangements in the Arctic": Promoting Sustainability of Indigenous Communities in Areas of Resource Extraction" in Arctic and International Relations Series, Fall 4 (2016) pp. 18-21; Tysiachniouk, Maria "Benefit Sharing Arrangements in the Russian North and Alaska" in Russian Analytical Digest, 202 (2017) pp. 2-5.

20. Tysiachniouk, Maria, "Benefit Sharing Arrangements in the Arctic: Promoting Sustainability of Indigenous Communities in Areas of Resource Extraction" in International Relations Series 4 (Fall), Canadian Studies Center, University of Washington, Seattle, Fall 2016, 4(2016) pp.18-21 https://jsis.washington.edu/arctic/research/arctic-and-international-relations-series/accessed 07.10 .2018 .

21. Henry et al. (2016).

22. Tysiachniouk, Maria, Henry, Laura A., Lamers, Machiel, and Jan P.M. van Tatenhove, "Oil And Indigenous People in Sub-Arctic Russia: Rethinking Equity and Governance in Benefit Sharing Agreements” in Energy Research Eo Social Science 37 (2018) pp. 140-152; Tulaeva, Svetlana and Maria Tysiachniouk, "Global Standards and Benefit Sharing of Russian and Transnational Oil Companies on Sakhalin Island of the Russian Far East” in Russian Analytical Digest, 202 (2017) pp. 10-13.

23. Kryazhkov, Vladimir, "Korennie Malochislennie Narodi Severa v Rossiiskom Prave” Moskva: Norma 2010.

24. Alferova, Liudmila, "Legal Provisions for Safeguarding the Rights of Indigenous Minorities of the Rights of Indigenous Minorities of the Region (Yugra), in Relation to Protection of Their Ancestral Lands, Traditional Ways of Life, and Livelihood Activities" in Sibirica 5, 2(2006) pp. 153-160.

25. Novikova, Natalia, Okhotniki I Neftianniki: Issledovanie po Iuridicheskoi Antropologii, Institut etnologii I antropologii: Moskva 2014, p. 324.

26. Dudeck, Stephan, Rud', Aleksei Anatol'evich, Havelka, Rudolf, Terebikhin, Nikolai Mikhailovich, and Marina Nikolaevna Melyutina, "Safeguarding Sacred Sites in the Subarctic ZoneThree Case Studies from Northern Russia” in Heinämäki L., Herrmann T. (eds) Experiencing 
and Protecting Sacred Natural Sites of Sámi and other Indigenous Peoples, Springer Polar Sciences (2017) pp. 159-180; Harjuchi, Galina P., "Nenetskie svjatilischa i Ih Klassifikaciya" in Arheologija i etnologija. Materialy nauchno issledovatel'skoj konferencii po itogam polevyh issledovanij, Nauchnyj vestnik 3 Salehard (2000) pp.77-79; Terekhin, Sergei, "Etnokulturnoe nasledie" in Moscovichenko (ed.) Prirodnii Park Numto: Priroda i Etnokulturnoe Nasledie, Surgut: OAO Surgutneftegaz (2017) pp. 118-123.

27. Zubarevich, Natalia, Regiony Rossii: Neravenstvo, Krizis, Modernizatsiya Nezavisimyi institute socialnoi politiki, Moskva 2010.

28. Novikova, Natalia, “Okhotniki I Neftianniki: Issledovanie po Iuridicheskoi Antropologii” Institut etnologii I antropologii: Moskva 2014, p. 206.

29. Interview \# 8. Representative of the Surgutneftegaz company.

30. Pristupa, Alexey O., Maria Tysiachniouk, Arthur P.J. Mol, Rik Leemans, Tatiana Minayeva, and Anastasia Markina. "Can zoning resolve nature use conflicts? The case of the Numto Nature Park in the Russian Arctic.” fournal of Environmental Planning and Management (2017): 1-27.

31. Shvarts, Evgeny A., Pakhalov, Alexander M. and Alexey Knizhnikov. "Assessment of environmental responsibility of oil and gas companies in Russia: the rating method." fournal of Cleaner Production 127 (2016): 143-151.

32. Interview 8.

33. Interview \# 2. Head of the Department of Land Use Planning and Control.

34. Tulaeva, Svetlana, and Maria Tysiachniouk. "Benefit-sharing arrangements between oil companies and indigenous people in Russian Northern regions.” Sustainability 9.8 (2017): 1326.

35. Interview \# 21. Deputy Head of the Beloyarsky Municipality.

36. Interview \# 21. Deputy Head of the Beloyarsky Municipality.

37. Interview \# 3. Head of the Department of the Environment.

38. Interview \# 2. Head of the Department of Land Use Planning and Control.

39. Interview \# 2. Head of the Department of Land Use Planning and Control.

40. Interview \# 6. Chief surveyor (marksheider) from Nizhnesortymskneft oil and gas extraction administration.

41. Interview \# 47. Representatives of the youth organization for Ob-Ugric Peoples.

42. Interview \# 29. Indigenous leader.

43. Interview \# 39. Indigenous inhabitant of Numto Nature Park.

44. Interview \# 35. Indigenous inhabitant of Numto Nature Park.

45. Interview \# 32. Indigenous inhabitant of Numto Nature Park.

46. Savishinsky, Joel S. "The ambiguities of alcohol: Deviance, drinking and meaning in a Canadian Native community." Anthropologica (1991): 81-98.

47. Interview \# 33. Indigenous inhabitant of Numto Nature Park.

48. Intervivew \# 29. Indigenous leader.

49. Interview \# 40. Indigenous inhabitant of Numto Nature Park.

50. Interview \# 40. Indigenous inhabitant of Numto Nature Park.

51. FPIC is a legal framework that requires consent of indigenous peoples before any activity can be carried out on their traditional territories; see Buxton, Abbi, and Wilson, Emma, FPIC and the extractive industries: A guide to applying the spirit of free, prior and informed consent in industrial projects, London, International Institute for Environment and Development 2013; Wilson, Emma "What is Free, Prior and Informed Consent (FPIC)?" http:// www.arran.no/evaluating-ethical-guidelines/?article $=116$, accessed 06.01.2018; Wilson (2016)

52. Wynberg, Rachel, "Rhetoric, Realism and Benefit Sharing” in World Intellectual Property 7 (2004) pp. 854-76.

53. Henry et al,. 2016.

54. Kunanayagam and Tomlinson (2011). 


\section{Dr. Maria Tysiachniouk and Dr. Irina Olimpieva}

55. Stammler, Florian and Emma Wilson, "Dialogue for Development: An Explanation of Relations Between Oil and Gas Companies, Communities and the State" in Siberica 5, 2(2006) pp. 1-42.

56. Laasonen, Salla, Fougère, Martin, and Arno Kourula, "Dominant Articulations in Academic Business and Society Discourse on NGO-Business Relations: A Critical Assessment" in Fournal of Business Ethics 109, 4(2012) pp. 521-545; Freeman, R. Edward, Strategic management: A stakeholder approach. Cambridge University Press, 2010; Friedman, Andrew L., and Miles. Stakeholders: Theory and practice. Oxford University Press on Demand, 2006. Samantha.

57. Tysiachniouk, Maria, Andrey Petrov, Vera Kuklina, and Natalia Krasnoshtanova. "Between Soviet Legacy and Corporate Social Responsibility: Emerging Benefit Sharing Frameworks in the Irkutsk Oil Region, Russia." Sustainability 10, no. 9 (2018): 3334; Tysiachniouk, Maria, Laura A. Henry, Machiel Lamers, and Jan PM van Tatenhove. "Oil and indigenous people in sub-Arctic Russia: Rethinking equity and governance in benefit sharing agreements." Energy Research \& Social Science 37 (2018): 140-152.

58. Stammler, Florian and Aitalina Ivanova, "Resources, rights and communities: extractive mega-projects and local people in the Russian Arctic” in Europe-Asia Studies 68, no. 7 (2016) pp. 1220-1244.

59. Yakovleva, Natalia. "Land, Oil, and Indigenous People in the Russian North: A Case Study of the Oil Pipeline and Evenki in Aldan" in Natural Resource Extraction and Indigenous Livelihoods: Development Challenges in an Era of Globalization, Ashgate Publishing UK, 2014, pp. 147-174; Stammler and Peskov (2008).

60. Interview \# 21. Deputy Head of the Beloyarsky Municipality.

61. Interview \# 2. Head of the Department of Land Use Planning and Control.

62. Interview \# 4. Head of the Department of Land Use Planning and Control.

63. McDermott, Melanie, Mahanty, Sango, and Kate Schreckenberg, "Examining Equity: A Multidimensional Framework for Assessing Equity in Payments for Ecosystem Services" in Environmental Science and Policy 33 (2013) pp. 416-427; Morgera, Elisa, "The Need for an International Legal Concept of Fair and Equitable Benefit Sharing” in European fournal of International Law 27, no. 2 (2016) pp. 353-383; Tysiachniouk, Maria S., and Andrey N. Petrov, "Benefit Sharing in the Arctic Energy Sector: Perspectives on Corporate Policies and Practices in Northern Russia and Alaska" in Energy Research E Social Science 39 (2018) pp. 29-34; Tysiachniouk, Maria, Henry, Laura A., Lamers, Machiel, and Jan P.M. van Tatenhove, "Oil Extraction and Benefit Sharing in an Illiberal Context: The Nenets and Komi-Izhemtsi Indigenous Peoples in the Russian Arctic” in Society Eo Natural Resources 31, no. 5 (2018) pp. 556-579; Tysiachniouk, Maria, Henry, Laura A. Lamers, Machiel, and Jan P.M. van Tatenhove, "Oil and Indigenous People in Sub-Arctic Russia: Rethinking Equity and Governance in Benefit Sharing Agreements" in Energy Research E Social Science 37 (2018): 140-152.

64. Pristupa et al., (2017).

65. Henry et al., (2016).

\section{Appendix 1. List of interviews}

The oil company Surgutneftegaz

1. Head of the Directorate of Environmental Safety and Environmental Management

2. Head of the Department of Land Use Planning and Control

3. Head of the Department of the Environment

4. Head of the Department of Indigenous Populations of the Directorate of Land Management 
5. Head of the Department for Environmental Monitoring and Information Technologies

6. Chief Surveyor (Marksheider) from Nizhnesortymskneft Oil and Gas Extraction Administration

7. Head of the Department of the Environment from Nizhnesortymskneft Oil and Gas Extraction Administration

8-10. Representatives of the oil company "Surgutneftegaz"

11-13. Workmen at the booster compressor station

The administration of Numto Nature Park

14. Director of the Park

15. Deputy Director for Protection of the Natural Ecosystem

16. Research officer

The administration of the Beloyarsky district of KMAO-Yugra

17. Head of the village Kazym

18. Deputy Head of the village Kazym

19. Deputy Head of the Department for the Environment and Indigenous Populations

20. Representative of Beloyarsky municipality

21. Deputy Head of the Beloyarsky municipality

22. Representative of Federal Service for Oversight of Natural Resource Use (Rosprirodnadzor)

23. Representative of Beloyarsky Forestry Administration

24. Director of the reindeer company 'Kazym'

The administration of KMAO-Yugra

25. Head of the Division for Specially Protected Natural Areas of the Department of Natural Resources and Non-Raw Materials Sector

26. Advisor of the Division for Specially Protected Natural Areas

27. First Deputy Director of the Department of Natural Resources and NonRaw Materials Sector

Indigenous people

28-29. Indigenous leaders

30-41. Indigenous inhabitants of Numto Nature Park

Experts and scientists

42-45. Expert biologists 
Dr. Maria Tysiachniouk and Dr. Irina Olimpieva

Civil society organisations

46. Representative of the Assembly of the Small Indigenous Peoples of the North at the Duma (Council) of the Administration of KMAO-Yugra

47-48. Representatives of the youth organization for Ob-Ugric Peoples

49. Representative of the NGO 'Ugra Salvation', Beloyarsky branch

50-51. Representatives of Greenpeace Russia 